\title{
LITERACY COMPETENCE AND HIGH ORDER THINKING SKILLS IN CURRICULUM 2013 IMPLEMENTATION
}

\section{Yuyu Yuliati, Dudu Suhandi Saputra}

Universitas Majalengka

yuyuyuliati74@gmail.com

\section{Article History}

accepted 30/09/2018

approved 12/10/2018

published 30/10/2018

\section{Keywords}

Literacy, high-level thinking skills, 2013 curriculum

\begin{abstract}
The implementation of the curriculum 2013 at the primary and secondary education levels is carried out in order to equip students with complete competencies to face challenges in the 21 st century. Therefore, such conditions become special challenges for teachers to prepare superior human resources through the development of literacy and high order thinking skills. This study provides an overview of the development of literacy competence and high order thinking skills in the curriculum 2013 implementation. The results of the study show that literacy competence and higher order thinking skills are demands of the curriculum 2013 development, in which the development is carried out through a learning process that puts students active in scientific work through problem solving activities and involving students in reading habitual activities through school literacy movements.
\end{abstract}

Social, Humanities, and Education Studies (SHEs): Conference Series https://jurnal.uns.ac.id/shes
p-ISSN 2620-9284

e-ISSN 2620-9292 


\section{PENDAHULUAN}

Abad-21 merupakan abad dimana kemajuan teknologi informasi dan komunikasi berkembang dengan cepat yang memberikan dampak pada berbagai bidang termasuk bidang pendidikan. Dengan demikian sektor pendidikan sudah selayaknya melakukan berbagai transformasi diantaranya yaitu dengan melakukan pengembangan kurikulum, hal ini dikarenakan kurikulum memiliki fungsi dan peranan yang sangat penting yaitu sebagai petunjuk terhadap keberhasilan proses pendidikan. Pengembangan kurikulum diperlukan karena semakin kompleksnya tantangan masa depan yang dihadapi baik secara internal maupun eksternal, selain itu terdapat beberapa hal lain yang juga mendasari pengemabangan kurikulum harus segera dilakukan yaitu seperti kompetensi yang harus dimiliki peserta didik di masa yang akan datang dan berbagai fenomena negative yang muncul akibat berkembangan zaman.

Perubahan kurikulum dari kurikulum tingkat satuan pendidikan menjadi kurikulum 2013 merupakan salah satu upaya pemerintah untuk meningkatkan mutu pendidikan sehingga dapat menghasilkan sumber daya manusia yang dapat disejajarkan bahkan mampu bersaing dengan sumber daya manusia dari negara lain dalam menghadapi berbagai isu-isu global. Kurikulum 2013 diharapkan dapat dijadikan sebagai bagian dari kebijakan strategis dalam menghadapi tantangan dan tuntutan masyarakat Indonesia di masa kini dan masa yang akan datang dimana melalui kurikulum ini diharapkan mampu mengarahkan peserta didik dapat menyesuaikan dirinya dengan lingkungan baik fisik mapun sosial yang kian hari kian mengalami perubahan. Berdasar pada penjelasan tersebut maka implementasi kurikulum 2013 berupaya untuk menghasilkan sumber daya manusia yang utuh, yaitu pribadi yang mampu berkolaborasi, mampu berkomunikasi dengan baik, memiliki keterampilan berpikir tingkat tinggi atau high order thinking skills (HOTS), serta mampu memecahkan berbagai permasalahan. Hal ini sejalan dengan pendapat Morocco, et al. (2008: 5), terdapat empat kompetensi yang harus dimiliki peserta didik di abad 21 ini yaitu conceptual understanding, critical thinking, creative thinking, dan collaboration and communication.

Keterampilan berpikir tingkat tinggi merupakan aspek penting dalam proses pendidikan, karena pemikiran seseorang dapat mempengaruhi kemampuan, kecepatan, dan efektivitas pembelajaran. Students with HOTS are able to earn, improve their performance and reduce their weaknesses (Tanujaya, mumu \& Margano, 2017). HOTS diperlukan untuk memudahkan siswa dalam memecahkan berbagai masalah, hal ini tercantum dalam Standar Kompetensi Lulusan (SKL) satuan pendidikan dasar dan menengah yang disebutkan bahwa siswa harus dapat menunjukan kemampuan berpikir logis, kritis, dan kreatif dalam membangun, menggunakan, dan menerapkan informasi tentang lingkungan sekitar untuk mampu menyelesaikan masalah (BNSP, 2006). Pogrow (2005) states that HOTS are valued because they are believed to prepare students better for the challenges both in advanced academic life and adult's work and responsibility in daily basis. Siswa yang memiliki tingkat HOTS yang baik diharapkan dapat berhasil dalam studi dan kehidupannya kelak. Pada implemetasinya kurikulum 2013 menekankan pada pengembangan HOTS dengan memberdayakan potensi nalar siswa untuk dapat memecahkan permasalahan melalui berbagai kegiatan pemecahan masalah.

Pada pengembangan kurikulum 2013 dalam rangka mempersiapkan SDM yang unggul dan kompetitif, selain keterampilan berpikir tingkat tinggi atau HOTS penekanan juga diberikan pada pengembangan kemampuan literasi. Penekanan ini dilatarbelakangi oleh kemampuan literasi siswa Indonesia saat ini dari beberapa penelitian masih cenderung belum sesuai dengan harapan. Data PISA (Programe for International Student Assessment) menunjukan bahwa kemampuan membaca siswa Indonesia masih dibawah rata-rata jika dibandingkan dengan rerata skor internasional dan secara umum, pengukuran membaca ini berorientasi pada pemahaman bacaan, 
menggunakan bacaan dan merefleksikan hasil bacaan dalam bentuk tulisan. Sebagaimana dikutip dari The Organization for Economic Co-operation and Development (OECD) peringkat Indonesia di PISA pada tahun 2015 berada di posisi 62 dari 70 negara yang ikut serta, perolehan skor siswa Indonesia untuk kemampuan membaca yaitu 397 jauh dibawah skor standar internasional yang ditetapkan oleh lembaga OECD yaitu sebesar 497(OECD, 2015). Selanjutnya Suragangga, M. (2017) menyebutkan bahwa Indonesia sedang mengalami darurat tingkat keaksaraan yang akan berdampak pada kualitas pendidikan dan SDM. Dengan melihat data tersebut nampaknya perlu dilakukan reorientasi pembelajaran pada jenjang pendidikan dasar dan menengah. Pada jenjang ini guru harus memiliki perhatian khusus pada pengembangan literasi peserta didik. Pada kurikulum 2013 kemampuan literasi dikembangkan melalui pembelajaran Bahasa Indonesia yaitu melalui pengembangan kemampuan membaca, menulis, dan berpikir kritis yang didukung pula oleh Gerakan Literasi Sekolah. Literasi merupakan kemampuan melek huruf, yaitu kemampuan memahami sesuatu karena membaca informasi yang tepat dan melakukan sesuatu berdasarkan pemahamannya terhadap isi bacaan.

Tulisan ini berisi pembahasan terkait urgensi pengembangan kemapuan literasi dan keterampilan berpikir tingkat tinggi pada kurikulum 2013 sebagai upaya untuk mempersiapkan peserta didik menjadi SDM yang produktif, kreatif, inovatif, dan afektif. Kajian ini merupakan kajian konseptual menggunakan studi literatur yang bersumber dari berbagai terkait.

\section{HASIL DAN PEMBAHASAN}

Tujuan kurikulum 2013 yaitu untuk menghasilkan lulusan yang produktif, kreatif, inovatif, kompetitif, mampu berkolaborasi, dan berkarakter dengan menitik beratkan pada peningkatan dan keseimbangan soft skills dan hard skills. Pada pelaksanaannya kurikulum 2013 mengintegrasikan tiga ranah kompetensi yaitu sikap, pengetahuan, dan keterampilan yang terangkum dalam Kompetensi Inti. Selanjutnya kompetensi dasar dikembangkan dari kompetensi inti. Untuk mencapai keberhasilan pencapaian tujuan pembelajaran, pada pelaksanaannya kurikulum 2013 menerapkan proses pembelajaran secara tematik integrative yang berorientasi pada proses berpikir melalui langkah kerja ilmiah mengamati, mempertanyakan, mengumpulkan informasi, menalar, lalu mengkomunikasikan. Pembelajaran diarahkan untuk mendorong siswa untuk mencari tahu, merumuskan dan menyelesaikan permasalahan, melatih berpikir analitis dalam pengambilan keputusan, dan menekankan pentingnya kerjasama dan kolaborasi dalam menyelesaikan permasalahan sehingga system penilaian dilakukan dengan cara penilaian otentik. Selanjutnya rancangan kurikulum 2013 juga memberikan penekanan pada ketercapaian kompetensi literasi dan keterampilan berpikir tingkat tinggi, hal ini karena kegiatan literasi mampu mengembangkan keterampilan berpikir tingkat tinggi. Keterampilan berpikir tingkat tinggi yang dapat dilatih melalui kegiatan literasi yaitu berpikir kritis dan kreatif. Berikut merupakan gambaran pengembangan literasi dan keterampilan berpikir tingkat tinggi pada implementasi kurikulum 2013.

1. Upaya mengembangkan literasi

Literasi dapat diartikan sebagai kemampuan membaca dan menulis (Abidin, 2015: 6). Kemampuan literasi yang baik pada siswa akan memungkinkan siswa mengembangkan diri secara maksimal. Sang, Y (2017) the literacy education should address the corresponding issues in order to better prepare students to participate in social and cultural activities in the modern society. Untuk mencapai kemampuan literasi yang baik pembelajaran literasi merupakan hal pokok yang harus dilakukan terutama pada tingkat dasar. Kalantzis \& Cope (2008) The goal of literacy education is to induct students into the standard written form through a pedagogy of transmission so as to reproduce the established cultural and linguistic forms. Selanjutnya tujuan 
pembelajaran literasi juga dijelaskan oleh The Ontario ministry of education yaitu untuk membentuk siswa menjadi pembaca, penulis yang strategis; meningkatkan dan mengembangkan kemampuan berpikir; upaya meningkatkan motivasi dan mengembangkan kemandirian belajar siswa sehingga menjadi pembelajar yang kreatif, inovatif, produktif, dan berkarakter (Nurkaeti, 2016). Namun penelitian Tryanasari, D., Aprilia, S., \& Cahya, W. (2017) menjelaskan bahwa pembelajaran literasi belum berjalan dengan optimal karena terkendala factor pemahaman guru terhadap pembelajaran literasi dan kebijakan sekolah yang belum membentuk tim gerakan literasi sekolah.

Tujuan pengembangan literasi membaca pada kurikulum 2013 yaitu sebagai langkah untuk membiasakan siswa dapat berpikir kritis dan kreatif dalam memahami isi bacaan. Pembelajaran literasi ini dilakukan melalui gerakan literasi sekolah dengan kegiatan pembiasaan, pengembangan, dan pembelajaran. Pembiasaan membaca sebagai bentuk pembelajaran literasi dilakukan oleh siswa 15 menit sebelum pembelajaran dimulai dengan membaca buku bacaan nonpelajaran yang kemudian dilanjutkan dengan kegiatan pembelajaran untuk meningkatkan literasi membaca di semua mata pelajaran.

2. Upaya mengembangkan keterampilan berpikir tingkat tinggi atau HOTS

Higher Order Thinking Skills (HOTS) is a thinking process, which consists of complicated procedures and needs to be based on various skills such as analysis, synthesis, comparison, inference, interpretation, assessment, and inductive and deductive reasoning to be employed to solve unfamiliar problems (Budsankom, et al., 2015). Ramos et al. (2013), states that HOTS include skill such as creative and critical thinking, analysis, problem solving, and visualization. Pengembangan keterampilan berpikir ini pada kurikulum 2013 bertujuan untuk mempersiapkan siswa supaya dapat lebih mudah menyelesaikan berbagai permasalahan. Guilford (Tan, 2009: 7) mendefinisikan berpikir kreatif yaitu berpikir untuk memberikan macam-macam kemungkinan jawaban benar ataupun cara terhadap suatu masalah berdasarkan informasi yang diberikan dengan penekanan pada jumlah dan kesesuaian. Adapun seseorang dikatakan terampil berpikir kreatif apabila mampu berpikir lancar (fluency) yaitu kemampuan mengeluarkan ide atau gagasan yang benar sebanyak mungkin secara jelas, berpikir luwes (flexibility) yaitu kemampuan untuk mengeluarkan banyak ide atau gagasan yang beragam, berpikir merinci (elaboration) yaitu kemampuan untuk menjelaskan faktor-faktor yang mempengaruhi dan menambah detail dari ide atau gagasannya sehingga lebih bernilai, dan berpikir orisinil (originality) yaitu kemampuan untuk mengeluarkan ide atau gagasan yang unik dan tidak biasanya. Beberapa aktivitas pembelajaran yang dapat mendorong siswa mengembangkan keterampilan berpikir kreatif diantaranya dengan menerka akibat suatu kejadian. Melalui aktivitas ini siswa ditugaskan untuk membuat daftar tentang akibat yang mungkin akan terjadi atas peristiwa atau masalah yang diajukan sebanyak mungkin. Selanjutnya memberi kesempatan kepada siswa untuk memberikan jawaban benar lebih dari satu dan berbeda akan mendorong siswa berpikir luwes.

Selain berpikir kreatif yang juga merupakan bagian dari HOTS adalah keterampilan berpikir kritis. Menurut Chance (Schneider, 2002: 1) berpikir kritis merupakan the ability to analyze facts, generate and organize ideas, defend opinions, make comparisons, draw inferences, evaluate arguments and solve problems. Kemampuan berpikir kritis berguna untuk merespon secara cepat dalam menangani suatu masalah yang terjadi, namun selalu didasarkan pada keakuratan dalam mengidentifikasi masalah. Sehingga memperoleh pemecahan masalah yang lebih cepat, baik serta berkualitas tinggi. Terdapat beberapa cara yang dapat dilakukan untuk meningkatkan keterampilan berpikir kritis menurut (Wright dkk. dalam 
Hassoubah, 2008: 96-100) diantaranya adalah membaca dengan kritis, meningkatkan daya analisis, dan mengembangkan kemampuan observasi/mengamati.

Keterampilan berpikir tingkat tinggi pada kurikulum 2013 dikembangkan melalui proses pembelajaran yang beroriestasi pada paradigma learning. Pada prosesnya siswa belajar melalui langkah kerja imiah meliputi mengamati, menanya, mengumpulkan informasi, menalar, dan mengomunikasikan untuk melakukan pemecahan masalah. Kegiatan ini diharapkan mampu mengarahkan pembelajaran menjadi lebih aktif, kolaboratif, dan partisipatif, serta mampu merangsang kemampuan berpikir kritis dan analitis siswa, bahkan sampai membuat siswa menghasilkan sebuah karya. Selanjutnya kurikulum 2013 juga menyarankan untuk menerapan beberapa model pembelajaran seperti pembelajaran berbasis proyek, pembelajaran berbasis masalah, problem solving, dan discovery/inquiry learning. Melalui penerapan beberapa model tersebut dapat memberikan peluang bagi guru untuk menerapkan kegiatan pembelajaran pada level HOTS. Berikut merupakan beberapa penelitian yang menunjukan keefektivan model yang disarankan kurikulum 2013 dalam meningkatkan HOTS. Penelitian Yuliati, Y (2016) menunjukan bahwa kemampuan berpikir kreatif siswa yang menggunakan pembelajaran model PBM $(0,58)$ lebih baik daripada kemampuan berpikir kreatif siswa yang menggunakan pembelajaran bukan PBM $(0,15)$. Nur'Azizah, H., dkk. (2016) menunjukan bahwa peningkatan kemampuan berpikir kritis dengan perlakuan model pembelajaran inkuiri terbimbing lebih baik secara signifikan daripada pembelajaran konvensional. Selanjutnya penelitian Fitri, H., Dasna, W.I,. \& Suharjo. (2018) menunjukan bahwa terdapat pengaruh yang signifikan model PjBL terhadap kemampuan berpikir tingkat tinggi.

\section{SIMPULAN}

Pembelajaran literasi mampu mengembangkan keterampilan berpikir tingkat tinggi siswa. selanjutnya pengembangan keterampilan berpikir tinggi pada kurikulum 2013 bertujuan untuk mempersiapkan siswa supaya dapat lebih mudah menyelesaikan berbagai permasalahan. Kemampuan literasi dan keterampilan berpikir tingkat tinggi atau high order thinking skills (HOTS) pada implementasi kurikulum 2013 dikembangkan melalui pembelajaran yang berorientasi pada siswa aktif, dimana siswa diarahkan untuk mencari tahu, merumuskan dan menyelesaikan permasalahan, melatih berpikir analitis dalam pengambilan keputusan. Selanjutnya dilakukan pembiasaan membaca sebagai bentuk pembelajaran literasi.

\section{DAFTAR PUSTAKA}

Abidin, Y. (2014). Desain Sistem Pembelajaran Dalam Konteks Kurikulum 2013. Bandung: PT Refika Aditama.

Budsankom, et al. (2015). Factors affecting higher order thinking skills of students: A meta-analytic structural equation modeling study. Academic journals .10(19), pp. 2639- 2652.

Fitri, H., Dasna, W.I.. \& Suharjo. (2018). Pengaruh Model Project Based Learning (PjBL) Terhadap Kemampuan Berpikir Tingkat Tinggi Ditinjau dari Motivasi Berprestasi Siswa Kelas IV Sekolah Dasar. Jurnal Riset dan Konseptual. 3(2). HIm. 201-212.

Hassoubah, Z.I. (2008). Develoving creative and critical thingking skills (terjemahan). Bandung: Nuansa.

Kalantzis, M., \& Cope, B. (2008). Language education and multiliteracies. In S. May \& $\mathrm{H}$. Hornberger (Eds.), Encyclopedia of Language and Education, pp.195-211. NY: Springer.

Nurkaeti, N. (2016). Pembiasaan membaca sebagai wujud pembelajaran literasi di sekolah dasar. Prosiding seminar nasional pendidikan dasar sekolah pascasarjana universitas pendidikan Indonesia. Vol 2, hlm. 172-177. 
Nur'Azizah, H., dkk (2016). Pengaruh Model Pembelajaran Inkuiri Terbimbing Terhadap Kemampuan Berpikir Kritis Siswa Pada Materi Energi Bunyi. Jurnal pena ilmiah. 1(1). hlm. 51-60.

OECD. (2015). PISA 2015 Results. OECD. Diakses dari http://www.businessinsider.co.id/pisa-worldwide-ranking-of-math-sciencereading-skills-2016-12/.

Pogrow, S. (2005). HOTS revisited: A Thinking Development Approach to Reducing the Learning Gap after Grade 3. Phi Delta Kappan: 87, pp. 64-75.

Ramos, J. L.S., Dolipas, B. B., \& Villamore, B. B. (2013). High Order Thinking skill and academic performance in Physics of College Students: A Regression Analysis. International Journal of innovative Interdiciplinary Research. 4, pp. 48-60.

Schneider, Vera. (2002). Critical Thinking in the Elementary Classroom: Problems and Solutions. Educators Publishing Service, a division of Delta Education, LLC.

Suragangga, M. (2017). Mendidik lewat literasi untuk pendidikan berkualitas. Jurnal penjamin mutu Institut Hindu Dharma Negeri Denpasar : 3(2), hlm 154-163.

Sang, Y. (2017). Expanded Territories of "Literacy": New Literacies and Multiliteracies. Journal of Education and Practice. 8(8), pp. 16-19.

Tan, O.S. (2009). Problem Based Learning And Creativity. Singapura: cengage learning.

Tanujaya, mumu \& Margano. (2017). The Relationship between Higher Order Thinking Skills and Academic Performance of Student in Mathematics Instruction. Journal Canadian Center of Science and Education : 10(11), pp. 78-85.

Tryanasari, D., Aprilia, S., \& Cahya, W. (2017). Pembelajaran literasi di SDN Rejosari 1 Kecamatan Kawedan Kabupaten Magetan. Premiere education : 7(2), hlm 173179.

Yuliati, Y. (2016). Peningkatan Keterampilan Berpikir Kreatif Siswa Sekolah Dasar Melalui Model Pembelajaran Berbasis Masalah. Prosiding seminar nasional pendidikan dasar UPI. 2(1). hlm. 124-129. 